\title{
Evaluation of Food Barley Genotypes for Grain Yield and Agronomic Traits in the Central Highlands of Ethiopia
}

\author{
Tigist Shiferaw $^{1} \quad$ Thomas Tsige $^{1} \quad$ Adane Chofere $^{2} \quad$ Shimles Gezahegn $^{2} \quad$ Kefyalew Taye $^{3}$ \\ Wami Hailu ${ }^{1} \quad$ Berhane Lakew ${ }^{1}$ \\ 1.Holetta Agricultural Research Center, P.O. Box 31, Holetta, Ethiopia \\ 2.Kulumsa Agricultural Research Center, P.O. Box 489, Assela, Ethiopia \\ 3.Debreberhan Agricultural Research Center, P.O. Box 112, Debreberhan, Ethiopia
}

\begin{abstract}
The present study was undertaken to evaluate the performance of promising food barley genotypes for grain yield and yield related traits. The trial was conducted in 2017 and 2018 main cropping season using randomized complete block design with three replications. Variance analysis and GGE biplot were used to understand the nature of genotype $\times$ environment interaction $(G \times E)$ in a grain yield data collected from eighteen barley genotypes grown in eight environments (Location and year combinations). The combined analysis of variance (ANOVA) showed significantly higher genotype, environment and genotype by environment interaction effects for all the traits studied. Accordingly, genotypes EH1493 X HB1307 (G10) and HB 1307 X ND25160 (G2) showed the highest mean grain yield of $4558 \mathrm{~kg} \mathrm{ha}^{-1}$ and $4499 \mathrm{kgha}^{-1}$, respectively. GGE biplot showed that G10 was the winner genotype at BK18, DB18 and HO18 environments and it has good grain yield stability across the testing environments. Therefore, G10 is a potential candidate variety to be included in the variety verification trial for possible release.
\end{abstract}

Keywords: ANOVA, GGE biplot, grain yield, stability

DOI: $10.7176 /$ ALST/84-02

Publication date: December $31^{\text {st }} 2020$

\section{INTRODUCTION}

Barley (Hordeum vulgare L) is an important stable food crop and has high potential in narrowing food deficit and enables to achieve food security in Ethiopia. It sustains a livelihood of millions of people residing on the highlands and fetches a substantial income for farmers. It is widely grown in diverse rain-fed agro-ecological zones of Ethiopia at an altitude of 1400 to over 3600 m.a.s.l. The crop is more diversified and prominent in areas between 2300 to 3400 m.a.s.l (Zemede, 2002). Food barley is commonly cultivated in stressed areas where soil erosion, soil acidity, occasional drought or frost limits the choice of other crops. It is cultivated in different production systems, namely; early, late, Belg and residual moisture (Yirga et al, 1998).

Barley is the fifth important cereal crops after maize, tef, wheat and sorghum. It is produced on about 1 million hectares of land from which 2.0 million tons of grain are produced annually (CSA, 2018). The productivity of barley in Ethiopia is low $(2.1 \mathrm{t} / \mathrm{ha})$ as compared to world average of $3.1 \mathrm{t} / \mathrm{ha}$. The low productivity is mainly attributed to abiotic stresses (soil acidity, frost, water logging, low moisture and low soil fertility) and biotic stresses (diseases, pests and weeds).

In general, barley remains an important crop in the Ethiopian agriculture because of its role in providing food for the rapidly growing population (3.0 \% per year). Therefore, there is a need to focus on barley improvement and developing alternative varieties to the different production systems and agro ecologies. Variety development effort is a dynamic process as one breeding program is required to provide a large option of varieties for diverse environmental conditions. Moreover, available varieties become obsolete due to break down of disease resistance and poor performance. Hence, it is crucial to provide new improved varieties that could go with the improved production packages identified on a continuous basis. Increasing the productivity of food barley is very important for the resource poor smallholder farmers in Ethiopia to improve the output and income to satisfy the local food demand of the rapidly growing population.

The National Barley Research program at Holetta and Kulumsa in collaboration with D/Berhane regional research center has conducted a multi-location variety trial, including lines developed from local collections, introductions and local crosses with the main objective of identifying stable and superior varieties to be released for production and use in the future breeding.

\section{MATERIALS AND METHODS}

A total of eighteen food barley genotypes including three check varieties were evaluated using completely randomized block design with three replications. The experiment was executed at Holetta, Jeldu, Debrebirhan, Bekoji and Kofole during the main cropping season in 2017 and 2018 under rain-fed conditions. Descriptions of the testing sites are described in Table 1. The materials were evaluated for eight quantitative traits at eight locations across years (Table 2). The traits studied were days to heading (days), days to maturity (days), plant height ( $\mathrm{cm}$ ), 
thousand kernel weight $(\mathrm{gm})$, hectoliter weight $\left(\mathrm{Kg} \mathrm{hl}^{-1}\right)$, grain yield $\left(\mathrm{Kg} \mathrm{ha}^{-1}\right)$, scald and net blotch disease severity (\%). A plot size of $1.2 \mathrm{~m}$ by $2.5 \mathrm{~m}$ was used to lay the experiment and the spacing between blocks and plots within blocks were $1.5 \mathrm{~m}$ and $0.4 \mathrm{~m}$, respectively. Analysis of variance (ANOVA) was carried out using R software to determine the effect of genotype, environment and their interaction on various traits of the food barley genotypes. Linear mixed effect model (lmer) of package lme4 was used for data analysis and the environments were considered as random and genotypes as fixed effects (R Core Team, 2017). The following ANOVA models have been used to test the performance of genotypes at each and combined locations, respectively (Singh and Ceccarelli 1996).

$Y_{i j}=\mu+G_{i}+B_{j}+e_{i j}$ and $Y_{i j k}=\mu+G_{i}+E_{j}+G_{i j}+B k(j)+e_{i j k}$.

Where, $Y_{i j}=$ observed value of genotype $\mathrm{i}$ in block $\mathrm{j}, \mathrm{Y}_{\mathrm{ijk}}=$ observed value of genotype $\mathrm{i}$ in block $\mathrm{k}$ of environment $j, \mu=$ grand mean of the experiment, $G_{i}=$ the effect of genotype $i, B_{j}=$ the effect of block $j, B k_{(j)}=$ the effect of block $\mathrm{k}$ in environment $\mathrm{j}, \mathrm{e}_{\mathrm{ij}}=$ error effect of genotype $\mathrm{i}$ in block $\mathrm{j}, \mathrm{E}_{\mathrm{j}}=$ environment effect, $\mathrm{GE}_{\mathrm{ij}}=$ the interaction effect of genotype $\mathrm{i}$ with environment $\mathrm{j}, \mathrm{e}_{\mathrm{ijk}}=$ error (residual) effect of genotype $\mathrm{i}$ in block $\mathrm{k}$ of environment j. In addition GGE bi-plots were performed to determine stability of the tested food barley genotypes using GGEBiplotGUI package of R-software (R Core Team, 2017).

Table 1. Description of testing sites

\begin{tabular}{llllll}
\hline No. & Testing sites & Altitude $(\mathbf{m})$ & Rainfall $(\mathbf{m m})$ & Longitude & Latitude \\
\hline $\mathbf{1}$ & Holetta & 2400 & 1100 & $38^{\circ} 38^{\prime} \mathrm{E}$ & $9^{\circ} 00^{\prime} \mathrm{N}$ \\
$\mathbf{2}$ & Jeldu & 2800 & 1200 & $38^{\circ} 03^{\prime} \mathrm{E}$ & $9^{\circ} 17^{\prime} \mathrm{N}$ \\
$\mathbf{3}$ & D/Berhane & 2830 & 932 & $39^{\circ} 32^{\prime} \mathrm{E}$ & $9^{\circ} 41^{\prime} \mathrm{N}$ \\
$\mathbf{4}$ & Bekoji & 2810 & 1082 & $39^{\circ} 15^{\prime} \mathrm{E}$ & $7^{\circ} 15^{\prime} \mathrm{N}$ \\
$\mathbf{5}$ & Kofole & 2700 & 1232 & $38^{\circ} 45^{\prime} \mathrm{E}$ & $7^{\circ} 00 \mathrm{~N}$ \\
\hline
\end{tabular}

Table 2. Lists of genotypes and environments used for the experiment

\begin{tabular}{lllll}
\hline Entry & Genotype & Location & Year & Environment code \\
\hline G1 & EH 1493 x PPB 25 & Bekoji & 2017 & BK17 \\
G2 & HB 1307 x ND 25160 & Bekoji & 2018 & BK18 \\
G3 & HB 1493 x ND 25160 & Kofele & 2017 & KF17 \\
G4 & EH 1493 x HB 42 & Kofele & 2018 & KF18 \\
G5 & Cross \# 41/98 x HB 42 & Holetta & 2017 & HO17 \\
G6 & EH 1493 x Cross 41/98 & Holetta & 2018 & HO18 \\
G7 & ARDU 12-60B x HB 1307 & Jeldu & 2018 & JL18 \\
G8 & HB 1307 x PPB 25 & Debreberhane & 2018 & DB18 \\
G9 & HB 1307 x Cross \# 41/98 & & & \\
G10 & EH 1493 x HB 1307 & & \\
G11 & Estayesh x Lab \# 87 & & & \\
G12 & Cross \# 41/98 X HB 1307 & & & \\
G13 & Tolese x HB 1307 & & \\
G14 & HB 1307 X PPB 53 & & & \\
G15 & Shege X Cross \#41/98 & & & \\
G16 & HB 1965 & & & \\
G17 & HB 1966 & & \\
G18 & Local check & & & \\
\hline
\end{tabular}

\section{RESULTS AND DISCUSSION}

Combined analysis of variance showed that genotype, environment and the genotype $\mathrm{x}$ environment interaction had a highly significant effect on all the traits studied (Table 3). The significant genotype effect showed the existence of significant variability among the tested genotypes. Highly significant genotype $\mathrm{x}$ environment interaction effect observed in this trial showed the tested genotypes performed differently across the testing environments for the traits. Therefore, researches involved in the barley improvement program should have to see the adaptability of genotypes to different test environments. Similarly, significant difference among the testing environments also observed. In the present study all traits showed the higher contribution of the environmental component to the total sums of squares and similar results were reported by Abtew et al., (2015). 
Table 3. Mean square values for combined analysis of variance of 18 food barley genotypes

\begin{tabular}{llllllllll}
\hline & DF & DHE & DMA & PLH & SC(DF)§ & NB(DF)§ & TKW & HLW & GYLD \\
\hline Gen & 17 & $89.6^{* *}$ & $96.9^{* *}$ & $174^{* *}$ & $602(17)^{* *}$ & $131(17)^{* *}$ & $151.5^{* *}$ & $26.5^{* *}$ & $1448234^{* *}$ \\
Env & 7 & $2206^{* *}$ & $8145^{* *}$ & $5102^{* *}$ & $22733(5)^{* *}$ & $31876(5)^{* *}$ & $2104^{* *}$ & $1219^{* *}$ & $23019573^{* *}$ \\
Gen:env & 119 & $11.5^{* *}$ & $22.0^{* *}$ & $51^{* *}$ & $250(85)^{* *}$ & $89(85)^{* *}$ & $19.2^{* *}$ & $7.3^{*}$ & $1443851^{* *}$ \\
Env:rep & 16 & 8.3 & 13.7 & 155 & $383(12)^{* *}$ & $154(12)^{* *}$ & 10.4 & 7.9 & $2059673^{* *}$ \\
Residuals & 272 & 7.5 & 8.8 & 33 & $138(204)$ & $56(204)$ & 9.9 & 5.5 & 657602 \\
\hline CV & & 3.3 & 2.1 & 5.1 & 36.1 & 21.1 & 7.5 & 3.7 & 19.4 \\
Mean & & 82.7 & 140.8 & 113.5 & 32.5 & 35.6 & 42.1 & 64.1 & 4190.8
\end{tabular}

$\mathrm{DF}=$ degree of freedom, $\mathrm{DHE}=$ days to heading, $\mathrm{DMA}=$ days to maturity, $\mathrm{PLH}=$ plant height, $\mathrm{SC}=$ scaled,

$\mathrm{NB}=$ net blotch, $\mathrm{TKW}=$ thousand kernel weight, $\mathrm{HLW}=$ hectoliter weight, GYLD= grain yield, **, *

Significant at $5 \%$ and $1 \%$ probability level, ns=non significant, $\S$ these traits were not recorded at DB18 and JL18 mean squares under those traits are angular transformed values

Based on the average data over eight environments, G10 (4558 kg ha- $\left.{ }^{1}\right)$ and G2 (4499 kg ha- $\left.{ }^{1}\right)$ scored the highest mean grain yield, though not significantly different from the recently released standard check varieties (HB1965 and HB 1966). Accordingly, G10 and G2 had 9.75 and 8.33\% grain yield advantage over the highest yielding check variety (HB 1966) (Table 4). The highest mean hectoliter weight (HLW) and thousand kernel weight (TKW) values was scored by G7. The two high grain yielding genotypes (G10 and G2) also had higher HLW and moderate TKW values. Regarding disease related traits most test genotypes showed moderate tolerance to scald and net blotch disease. The check variety HB 1965 and 1966 scored 21.2 and $26.7 \%$ severity for scald and $33.3 \%$ and $32.8 \%$ severity for net blotch. Similarly, the candidate genotypes G10 and G2 also showed moderate scald $(36.2,29.0 \%)$ and net blotch $(39.0,37.2 \%)$ resistance, respectively. The ranges of plant height values of $106-115 \mathrm{~cm}$ were recorded with the lower end corresponding check variety HB 1965 while the upper end corresponds to the local check variety, this longer plant height is in agreement with the inherent nature of most local varieties. Furthermore, the phenological traits showed lower variability with, five and seven days differences in mean days to heading and maturity respectively (Table 4). Based on agronomic and grain physical quality traits (HLW and TKW), G10 is the top ranking genotype. Thus, G10 and the other two promising varieties, namely G2 and $\mathrm{G} 7 \mathrm{can}$ be used for future breeding program as donor parents.

Table 4. Means from the combined analysis of variance on 8 traits of 18 food barley genotypes tested at 8 environments.

\begin{tabular}{|c|c|c|c|c|c|c|c|c|c|}
\hline Trt\# & Genotype & DHE & DMA & PLH & SC§ & NB§ & TKW & HLW & GYLD \\
\hline G1 & EH $1493 \times$ PPB 25 & $80.9^{\mathrm{de}}$ & $144.3^{\mathrm{a}}$ & $109.7^{\mathrm{c}-\mathrm{f}}$ & $30.0^{\text {cde }}$ & $35.5^{b}$ & $45.6^{\mathrm{ab}}$ & $64.6^{\mathrm{bc}}$ & $4037^{\mathrm{abc}}$ \\
\hline $\mathrm{G} 2$ & HB $1307 \times$ ND 25160 & $82.4^{\mathrm{a}-\mathrm{e}}$ & $142.0^{\mathrm{abc}}$ & $109.8^{\mathrm{c}-\mathrm{f}}$ & $29.0^{\text {cde }}$ & $37.2^{\mathrm{ab}}$ & $43.0^{\mathrm{b}-\mathrm{e}}$ & $64.7^{\mathrm{abc}}$ & $4499^{a}$ \\
\hline G3 & HB $1493 \times$ ND 25160 & $84.8^{\mathrm{abc}}$ & $143.7^{\mathrm{a}}$ & $116.1^{\mathrm{a}}$ & $26.2^{\mathrm{de}}$ & $36.8^{\mathrm{ab}}$ & $45.6^{\mathrm{ab}}$ & $63.8^{\mathrm{bcd}}$ & $4103^{\mathrm{abc}}$ \\
\hline G4 & EH $1493 \times$ HB 42 & $80.7^{\mathrm{e}}$ & $141.2^{\mathrm{a}-\mathrm{d}}$ & $111.3^{\mathrm{a}-\mathrm{e}}$ & $31.2^{\mathrm{b}-\mathrm{e}}$ & $32.8^{\mathrm{b}}$ & $44.0^{\mathrm{a}-\mathrm{d}}$ & $64.5^{\mathrm{bc}}$ & $4331^{\mathrm{abc}}$ \\
\hline G5 & Cross \# 41/98 x HB 42 & $85.2^{\mathrm{ab}}$ & $144.8^{\mathrm{a}}$ & $113.6^{\mathrm{abc}}$ & $28.4^{\text {cde }}$ & $35.5^{\mathrm{b}}$ & $43.9^{\mathrm{a}-\mathrm{d}}$ & $64.4^{\mathrm{bc}}$ & $4270^{\mathrm{abc}}$ \\
\hline G6 & EH $1493 \times$ Cross 41/98 & $82.8^{\mathrm{a}-\mathrm{e}}$ & $141.5^{\mathrm{a}-\mathrm{d}}$ & $113.2^{\mathrm{abc}}$ & $35.6^{\mathrm{a}-\mathrm{d}}$ & $36.2^{\mathrm{b}}$ & $43.7^{\text {bcd }}$ & $64.3^{\mathrm{bc}}$ & $4262^{\mathrm{abc}}$ \\
\hline G7 & $\begin{array}{l}\text { ARDU 12-60B x HB } \\
1307\end{array}$ & $80.2^{\mathrm{e}}$ & $142.4^{\mathrm{ab}}$ & $113.1^{\mathrm{a}-\mathrm{d}}$ & $35.7^{\mathrm{a}-\mathrm{d}}$ & $35.6^{\mathrm{b}}$ & $47.9^{\mathrm{a}}$ & $66.7^{\mathrm{a}}$ & $3693^{\mathrm{bc}}$ \\
\hline G8 & HB $1307 \times$ PPB 25 & $82.1^{\mathrm{b}-\mathrm{e}}$ & 143 & $110.9^{\mathrm{b}-\mathrm{e}}$ & $32.9^{\mathrm{bcd}}$ & $34.5^{\mathrm{b}}$ & $43.8^{\mathrm{bcd}}$ & & $4326^{\mathrm{abc}}$ \\
\hline G9 & $\begin{array}{l}\text { HB } 1307 \times \text { x Cross \# } \\
41 / 98\end{array}$ & $83.9^{\mathrm{a}-\mathrm{d}}$ & $142.3^{\mathrm{ab}}$ & $108.3^{\mathrm{def}}$ & $29.5^{\text {cde }}$ & $34.5^{\mathrm{b}}$ & $42.7^{\mathrm{b}-\mathrm{e}}$ & $64.9^{\mathrm{abc}}$ & $4219^{a b c}$ \\
\hline G10 & EH 1493 x HB 1307 & $82.1^{\text {cde }}$ & $141.9^{\mathrm{a}-\mathrm{d}}$ & $109.9^{\mathrm{c}-\mathrm{f}}$ & $36.2^{\mathrm{a}-\mathrm{d}}$ & $39.0^{\mathrm{ab}}$ & $42.4^{\mathrm{b}-\mathrm{e}}$ & $65.5^{\mathrm{ab}}$ & $4558^{\mathrm{a}}$ \\
\hline G11 & Estayesh x Lab \# 87 & $85.5^{\mathrm{a}}$ & $143.6^{\mathrm{a}}$ & $113.2^{\mathrm{a}-\mathrm{d}}$ & $44.5^{\mathrm{a}}$ & $32.2^{b}$ & $40.0^{\mathrm{de}}$ & $64.4^{\mathrm{bc}}$ & $4408^{\mathrm{ab}}$ \\
\hline G12 & $\begin{array}{l}\text { Cross \# 41/98 X HB } \\
1307\end{array}$ & $80.6^{\mathrm{e}}$ & $139.4^{\mathrm{bcd}}$ & $110.4^{\mathrm{b}-\mathrm{f}}$ & $36.7^{\mathrm{a}-\mathrm{d}}$ & $34.5^{\mathrm{b}}$ & $41.4^{\text {cde }}$ & 65 & $79^{a b c}$ \\
\hline G13 & Tolese x HB 1307 & $82.2^{\mathrm{b}-\mathrm{e}}$ & 138 & $111.2^{\mathrm{a}-\mathrm{e}}$ & $31.2^{\mathrm{b}-\mathrm{e}}$ & $38.4^{\mathrm{ab}}$ & $39.4^{\mathrm{e}}$ & 64 & $4101^{\mathrm{abc}}$ \\
\hline G14 & HB 1307 X РPB 53 & $83.3^{\mathrm{a}-\mathrm{e}}$ & $141.4^{\mathrm{a}-\mathrm{d}}$ & $107.2^{\mathrm{ef}}$ & $38.4^{\mathrm{abc}}$ & $34.5^{b}$ & $41.5^{\mathrm{cde}}$ & $65.3^{\mathrm{ab}}$ & $4153^{\mathrm{abc}}$ \\
\hline G15 & Shege X Cross \#41/98 & $84.3^{\mathrm{abc}}$ & $143.3^{\mathrm{ab}}$ & $111.2^{\mathrm{a}-\mathrm{e}}$ & $41.7^{\mathrm{ab}}$ & $34.4^{\mathrm{b}}$ & $40.9^{\text {de }}$ & $65.0^{\mathrm{abc}}$ & $4357^{\mathrm{abc}}$ \\
\hline G16 & HB 1965 & $80.2^{\mathrm{e}}$ & $138.0^{\mathrm{d}}$ & $105.6^{\mathrm{f}}$ & $21.2^{\mathrm{e}}$ & $33.3^{b}$ & $40.1^{\text {de }}$ & $62.0^{\mathrm{d}}$ & $4035^{\mathrm{abc}}$ \\
\hline G17 & HB 1966 & $82.1^{\mathrm{b}-\mathrm{e}}$ & $143.9^{\mathrm{a}}$ & $109.2^{\mathrm{c}-\mathrm{f}}$ & $26.7^{\mathrm{de}}$ & $32.8^{b}$ & $44.1^{\mathrm{abcd}}$ & $64.0^{\mathrm{bcd}}$ & $4153^{\mathrm{abc}}$ \\
\hline G18 & Local check & $85.0^{\mathrm{abc}}$ & $142.7^{\mathrm{ab}}$ & $114.9^{\mathrm{ab}}$ & $30.0^{\text {cde }}$ & $43.4^{\mathrm{a}}$ & $45.1^{\mathrm{abc}}$ & $63.1^{\mathrm{cd}}$ & $3659^{c}$ \\
\hline
\end{tabular}

$\mathrm{DHE}=$ days to heading, $\mathrm{DMA}=$ days to maturity, $\mathrm{PLH}=$ plant height $(\mathrm{cm}), \mathrm{SC}=$ scaled $(\%), \mathrm{NB}=$ net blotch $(\%)$, $\mathrm{TKW}=$ thousand kernel weight $(\mathrm{g}), \mathrm{HLW}=$ hectoliter weight $\left(\mathrm{Kg} \mathrm{hl}^{-1}\right), \mathrm{GYLD}=$ grain yield $\left(\mathrm{Kg} \mathrm{ha}^{-1}\right)$, §these traits were not recorded at DB18 and JL18

Separate analysis for each of the test environments showed consistently large variation among test varieties for grain yield (Table 5). G10 and G2 gave consistently highest grain yield in all test environments exceeding the 
check varieties. These genotypes scored mean grain yield ranged from $3628-5440 \mathrm{~kg} \mathrm{ha}^{-1}$ and $3577-5389 \mathrm{~kg} \mathrm{ha}^{-1}$, respectively, and this showed both genotypes could have a potential to be selected for variety verification trial. (Table 5). The two standard check genotypes HB 1965 and HB1966 had relatively lower grain yield than the candidate genotypes across test environments. Beside G7 and local check G18 recorded lower mean values in all locations.

Table 5. Mean performance of grain yield $\left(\mathrm{Kgha}^{-1}\right)$ of food barley genotypes tested at eight environments

\begin{tabular}{|c|c|c|c|c|c|c|c|c|c|c|}
\hline $\begin{array}{l}\text { Trt } \\
\#\end{array}$ & Genotype & $\begin{array}{l}\text { BK1 } \\
7\end{array}$ & $\begin{array}{l}\text { HO1 } \\
7\end{array}$ & $\begin{array}{l}\text { KF1 } \\
7\end{array}$ & $\begin{array}{l}\text { BK1 } \\
8\end{array}$ & $\begin{array}{l}\text { DB1 } \\
8\end{array}$ & $\begin{array}{l}\text { HO1 } \\
8\end{array}$ & $\begin{array}{l}\text { JL1 } \\
8\end{array}$ & $\begin{array}{l}\text { KF1 } \\
8\end{array}$ & $\begin{array}{l}\text { Mea } \\
\text { n }\end{array}$ \\
\hline G1 & EH $1493 \times$ PPB 25 & 4906 & 3300 & 3094 & 4437 & 3906 & 4611 & 4438 & 3634 & 4037 \\
\hline G2 & HB $1307 \times$ ND 25160 & 5389 & 3783 & 3577 & 4920 & 4389 & 5094 & 4921 & 4117 & 4499 \\
\hline G3 & HB $1493 \times$ ND 25160 & 4957 & 3350 & 3145 & 4488 & 3956 & 4661 & 4488 & 3685 & 4103 \\
\hline G4 & EH $1493 \times$ HB 42 & 5214 & 3608 & 3403 & 4745 & 4214 & 4919 & 4746 & 3943 & 4331 \\
\hline G5 & Cross \# 41/98 x HB 42 & 5133 & 3526 & 3321 & 4664 & 4132 & 4837 & 4665 & 3861 & 4270 \\
\hline G6 & EH 1493 x Cross 41/98 & 5096 & 3489 & 3284 & 4627 & 4095 & 4800 & 4628 & 3824 & 4262 \\
\hline G7 & $\begin{array}{l}\text { ARDU } 12-60 B \quad x \quad H B \\
1307\end{array}$ & 4540 & 2934 & 2728 & 4071 & 3539 & 4244 & 4072 & 3268 & 3693 \\
\hline G8 & HB $1307 \times$ PPB 25 & 5197 & 3590 & 3385 & 4728 & 4196 & 4901 & 4729 & 3925 & 4326 \\
\hline G9 & HB 1307 x Cross \# 41/98 & 5069 & 3462 & 3257 & 4600 & 4068 & 4773 & 4601 & 3797 & 4219 \\
\hline G10 & EH 1493 x HB 1307 & 5440 & 3833 & 3628 & 4971 & 4439 & 5144 & 4972 & 4168 & 4558 \\
\hline G11 & Estayesh x Lab \# 87 & 5250 & 3644 & 3439 & 4782 & 4250 & 4955 & 4782 & 3979 & 4408 \\
\hline G12 & Cross \# 41/98 X HB 1307 & 5142 & 3536 & 3331 & 4673 & 4142 & 4847 & 4674 & 3871 & 4279 \\
\hline G13 & Tolese x HB 1307 & 4965 & 3359 & 3154 & 4496 & 3965 & 4670 & 4497 & 3694 & 4101 \\
\hline G14 & HB 1307 X PРB 53 & 5005 & 3399 & 3193 & 4536 & 4004 & 4709 & 4537 & 3733 & 4153 \\
\hline G15 & Shege X Cross \#41/98 & 5195 & 3589 & 3383 & 4726 & 4194 & 4899 & 4727 & 3923 & 4357 \\
\hline G16 & HB 1965 & 4908 & 3301 & 3096 & 4439 & 3907 & 4612 & 4440 & 3636 & 4035 \\
\hline G17 & HB 1966 & 5026 & 3419 & 3214 & 4557 & 4025 & 4730 & 4558 & 3754 & 4153 \\
\hline G18 & Local check & 4463 & 2857 & 2651 & 3994 & 3463 & 4168 & 3995 & 3192 & 3659 \\
\hline
\end{tabular}

Stability of the test genotypes across environments

The discussion in the previous variety trials based mostly on genotype main effect $(\mathrm{G})$ and genotype-byenvironment interactions (GE) are treated as noise or a confounding factor (Yan and Tinker, 2006). But recently various methods developed to study GxE interaction and determine whether or not a genotype is stable in performance over a range of environments. The GGE biplot method consists of a set of biplot interpretation methods to evaluate genotype and test-environment (Yan et al., 2007). The "Mean vs stability" view of GGE biplot helps to evaluate genotypes based on their mean performance and stability (Figure 1). The graph consists of $\mathrm{x}$ axis passes through the biplot origin and the marker of the average environment, which is defined by the average PC1 and PC2 scores of overall environments. The stability and average performance of the genotypes was measured by their projection to the Y-axis and X axis, respectively (Yan, 2001). Therefore, G10 had both the highest average yield and stability. Then G-2 scored the second highest mean grain yield performance, but relatively it lacks stability and more adapted to specific environment, HO18. Similarly G11 (Estayesh x Lab \# 87) had better mean grain yield and more adapted to environment, JL18. Among the check varieties G17 (HB 1966) revealed moderate mean grain yield and good stability. The local check variety G18 had the lowest average yield and the least stable variety (Figure 1).

The "which-won-where" pattern of a genotype by environment data set is an important feature of GGE biplot. The Biplot contain a polygon drown on genotypes that are furthest from the biplot origin so that all other genotypes are contained within polygon and these genotypes located on the vertices of the polygon performed either the best or the poorest in one or more environments (Yan and Tinker, 2006). The "which-won-where" view of the GGE biplot is an effective visual tool in mega-environment analysis (Yan et al., 2007). G10 was the winner in environments DB18, BK18 and HO17. G2 was more adapted to the testing environment HO18. G11 was the highest yielding genotype in environments JL18. The check genotype G17 (HB1966) was a vertex genotype with no testing location specifically adapted to it. The local check variety (G18) was relatively low yielding genotype at all environments (Figure 2). 
Mean vs. Stability

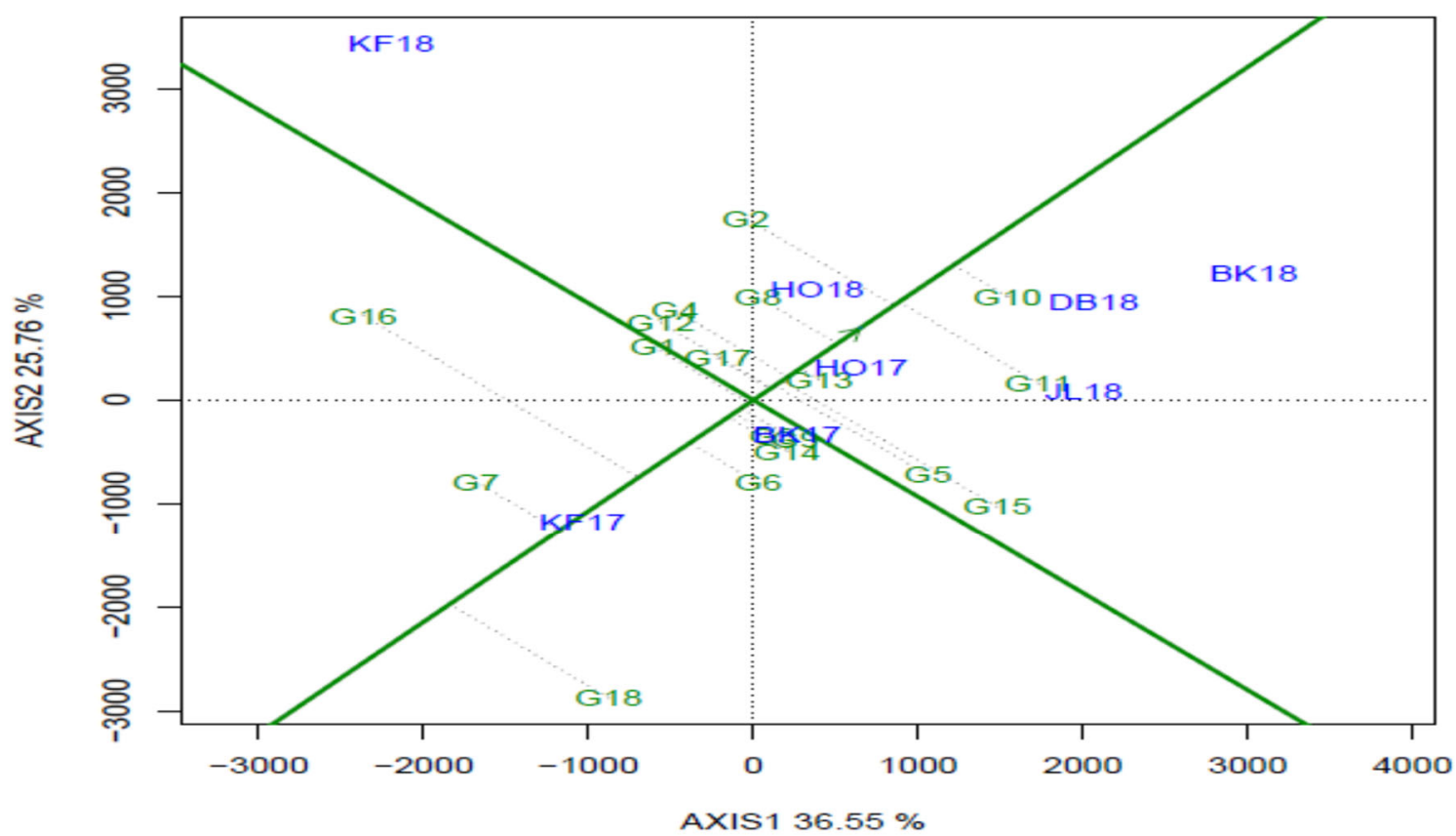

Figure 1. Mean grain yield performance and stability of genotypes based on the $\mathrm{G} \times \mathrm{E}$ data

Which Won Where/What

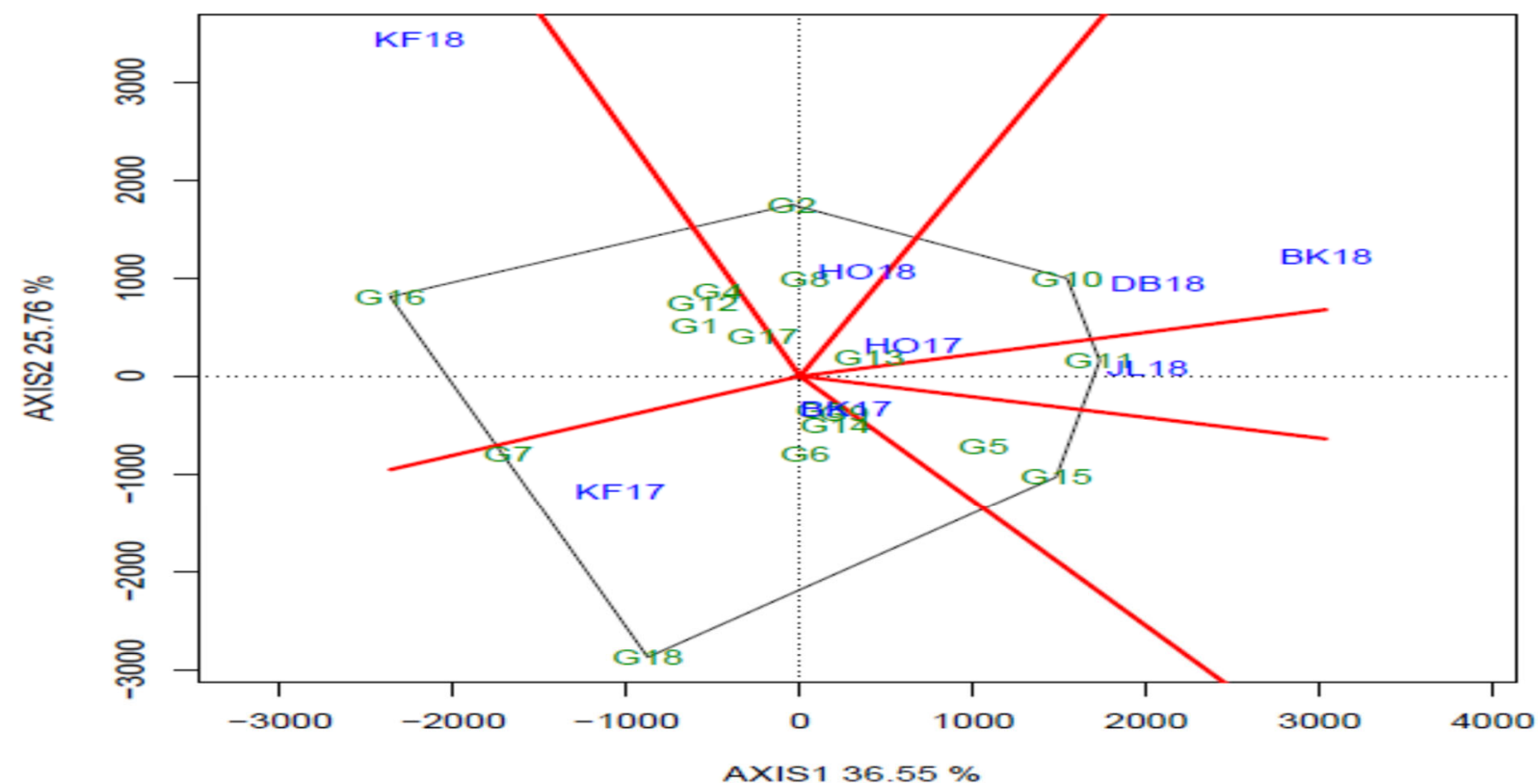

Figure 2. The which-won-where view of the GGE biplot of grain yield of Food barley genotypes based on the G $\times$ E data

\section{CONCLUSION}

In the present study, the eighteen food barley genotypes showed significant genetic, environmental and genotype by environment interaction effects for all traits considered in the experiment. Genotypes, G10 and G2 showed the highest mean grain yield potential at all environments. These genotypes showed moderately resistant to scald and net blotch, and acceptable TKW and HLW values. Based on "Mean vs stability" view of GGE biplot, G10 was the highest yielding and stable genotype. While G2 was the second highest yielding genotypes but it is relatively unstable. Similarly "Which won where" pattern of GGE biplot confirmed that G10 gave consistently highest mean grain yield across the test environments and G2 specifically adapted to HO18 environment. Therefore, based on mean performance and stability, G10 is the best potential variety identified for possible variety verification trial 
for the mega and other similar environments. In addition, G10 and the other two Genotypes, G2 and G7 will be included in the food barley crossing program as potential parents for their good yield potential and physical grain quality traits.

\section{REFERENCES}

Abtew, Wosene G., Lakew, Berhane, Haussmann, Bettina I. and Schmid, K.J., 2015. Ethiopian barley landraces show higher yield stability and comparable yield to improved varieties in multi-environment field trials. Journal of plant breeding and crop science, 7(8), pp.275-291.

CSA, 2018. Area and Production of Major Crops, Agricultural Sample Survey, 2017/18 (2010 E.C.). Central statistics Agency, Statistical Bulletin 586. Addis Abeba, Ethiopia

R Core Team, 2017. R: A language and environment for statistical computing. R Foundation for Statistical Computing, Vienna, Austria.URL http://www.R-project.org/.

Singh, R.K. and Chaudhury, B.D, 1996. Biometrical Method in Quantitative Genetic Analysis. Kalyani, Ludhiana.

Yan, W., 2001. GGEbiplot-A Windows application for graphical analysis of multi-environment trial data and other types of two-way data. Agronomy journal, 93(5), pp.1111-1118.

Yan, W. and Tinker, N.A., 2006. Biplot analysis of multi-environment trial data: Principles and applications. Canadian journal of plant science, 86(3), pp.623-645.

Yan, W., Kang, M.S., Ma, B., Woods, S. and Cornelius, P.L., 2007. GGE biplot vs. AMMI analysis of genotypeby-environment data. Crop science, 47(2), pp.643-653.

Yirga, Chilot, Fekadu Alemayehu and Woldeyesus Sinebo (Eds)., 1998. Barley-based Farming Systems in the Highlands of Ethiopia. Ethiopian Agricultural Research Organization. Addis Ababa, Ethiopia.

Zemede, A., 2002. The Barley of Ethiopia. In: Stephen, B.B (ed.). Genes in the Field. On-farm Conservation of Crop Diversity. Lewis Publisher, Boca Raton, pp 77-107. 